\title{
Productive opportunities, uncertainty, and science-based firm emergence
}

\author{
Marcela Miozzo • Lori DiVito
}

Accepted: 23 February 2018/Published online: 27 April 2018

(C) The Author(s) 2018

\begin{abstract}
We provide greater theoretical precision to the concept of productive opportunities of Penrose. We show firm emergence as a recursive cycle of changing productive opportunities. We show how those opportunities result from the technological base of the firm and are associated with the particular characteristics of the technology. We also show how productive opportunities require the assembly of different internal and external resources, and therefore partners. We address explicitly how the firm and its potential partners perceive uncertainty and single out the different mechanisms used by the firm to address uncertainty - envisioning, pooling, and staging - to secure resources from external partners and exploit the identified productive opportunities in a timely manner.
\end{abstract}

Keywords Productive opportunities · Uncertainty . Science-based firm $\cdot$ Penrose $\cdot$ Partnerships

JEL classification $\mathrm{D} 83 \cdot \mathrm{M} 13 \cdot \mathrm{O} 31 \cdot \mathrm{L} 26$

\footnotetext{
M. Miozzo

King's Business School, King's College London, Bush House, Strand, London WC2R 2LS, UK

e-mail: marcela.miozzo@kcl.ac.uk

L. DiVito $(\bowtie)$

Amsterdam School of International Business, Amsterdam University of Applied Sciences, Fraijlemaborg, 1331102 CV Amsterdam, The Netherlands e-mail: 1.e.d.divito@hva.nl
}

\section{Introduction}

A key policy concern is to foster entrepreneurial science-based activity to spur innovation and economic growth. Nevertheless, our understanding of how new science-based firms - research spin-offs from university departments or industrial firms - emerge is still underdeveloped. These firms must identify a productive opportunity, based on novel and often disruptive science and technology as well as largely tacit knowledge emerging from the research laboratory (Markman et al. 2008), and must frame this emergent knowledge into a viable business opportunity.

Typically emanating from a non-commercial environment, science-based firms face challenges in developing the necessary resources and competencies and in framing innovations commercially (Mustar et al. 2006; Rothaermel et al. 2007; Siegel et al. 2007; Vohora et al. 2004). Existing literature has concentrated on the different starting resource configurations (Druilhe and Garnsey 2004; Heirman and Clarysse 2004) and competencies needed to launch a science-based venture successfully (Rasmussen et al. 2011) and on how these evolve over time (Miozzo and DiVito 2016). While these contributions offer important insights, we know relatively little about how these firms emerge through identifying and developing commercially viable productive opportunities in a context of uncertainty and how they engage the necessary partners in a timely manner. We propose that an in-depth investigation into this emergence process is necessary in order to build a more thorough theoretical framework. 
To address this question, we build on and extend the concept of "productive opportunities" developed by Penrose (1959/2009). Penrose's writings predate the work of evolutionary economists on Schumpeterian innovation and entrepreneurship as the engine driving capitalism (Nelson and Winter 1982; Dosi et al. 1988). As such, we draw on contributions from evolutionary economics to provide greater theoretical precision to Penrose's concept of productive opportunities. We show firm emergence as a recursive cycle of changing productive opportunities. We also show how those opportunities result from the technological base of the firm and are associated with the particular characteristics of the technology. We depict how the different opportunities require the assembly and development of different internal and external resources, and therefore partners. We address explicitly how the firm and its potential partners perceive uncertainty and single out the different mechanisms used by the firm to address uncertaintyenvisioning, pooling, and staging - to secure resources from external partners and exploit the identified productive opportunities in a timely manner.

Our contribution to the literature is twofold. First, by observing how new science-based firms identify and develop their productive opportunities in a context of uncertainty, insights into entrepreneurship based on innovation (Acs et al. 2009) can be gained, which are useful for understanding the emergence of technology ventures in a dynamic environment in general. Second, by extending Penrose's concept of "productive opportunities," we address recent calls for resource-oriented firm growth studies to build more directly upon Penrose (Lockett et al. 2011; Nason and Wiklund 2015).

We provide next the theoretical framework. After that we describe the research design and data analysis. We then present the findings. A discussion and conclusion follow.

\section{Theoretical framework}

\subsection{Productive opportunities and firm emergence}

Evolutionary economics and strategic management of innovation scholars stress the important role of firms' search process in creating economic opportunities and finding sources of variety and new combinations of knowledge (Laursen 2012; Nelson and Winter 1982). For these scholars, knowledge is highly idiosyncratic to the firm and context-dependent, and does not flow freely between organizations. Firms' search is argued to follow established technological trajectories (Dosi 1988) and to be shaped by industry conditions - especially the degree of technological opportunities, appropriability, and cumulativeness of technological knowledge (Breschi et al. 2000; Klevorick et al. 1995; Levin et al. 1987).

Technological opportunities arise from scientific or technological knowledge and indicate, according to Malerba and Orsenigo (1996, 1997), the likelihood of innovation given investment in search. The sources and level of technological opportunities differ markedly among sectors, because in some sectors opportunities arise from scientific breakthroughs in universities, whereas in others from applied R\&D or engineering efforts (Freeman 1982; Rosenberg 1982). Some sectors (such as biopharmaceuticals) have high technological opportunities, enabling the easy entry of new entrepreneurial firms.

For the entrepreneurship literature, in contrast, concern with entrepreneurial or market opportunities (Shane and Venkataraman 2000) has directed the attention of scholars to the early stage of development of new firms and potential arbitrage profits. The debate is polarized between those who suggest that such opportunities are discovered and those who suggest they are created. One group suggests opportunities exist objectively and that the basis for entrepreneurship activity is unevenly distributed information across people (Eckhardt and Shane 2003; Shane 2000). The second group denies that characteristics of the opportunity can be discussed meaningfully without reference to the entrepreneur (Alvarez and Barney 2007; Alvarez et al. 2013). ${ }^{1}$

This paper builds on the view that opportunities are created over time, which is in line with both the perspective on technological opportunities from evolutionary economics and the entrepreneurship "creation" perspective. These positions have been fruitfully brought together by McKelvey (2016), who argues that, in their search processes, firms monitor three types of opportunities - technological opportunities, market opportunities, and productive opportunities. We extend this line of research by returning to Penrose's (1959/2009) work

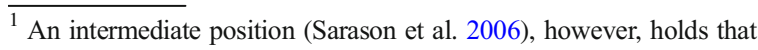
opportunities are subjective but can change considerably during their development, gaining greater objectification (Wood and McKinley 2010). Others suggest a need for a fundamental re-conceptualization of the "opportunity" concept (Davidsson 2015).
} 
and attempting to capture the intuition behind Penrose's conception of productive opportunities, reinterpreting and building on this conception by drawing on contributions from evolutionary economics.

We propose here that firm emergence can be regarded as a recursive cycle of changing productive opportunities. We define productive opportunities as the various productive possibilities around the firm's technological bases. Penrose argues that the productive activities of a firm are governed by what she calls its "productive opportunity," which "comprises all of the productive possibilities that its 'entrepreneurs' see and can take advantage of" (p. 28). The conception of the firm as a collection of productive resources and the idea that resources can provide a variety of different services are key to understanding the productive opportunities of the firm. It is the heterogeneity of the productive services derived potentially from its resources that gives each firm its unique nature. The heterogeneity in the services that can be provided from its material resources enables the same resources to be used in different ways and for different aims if the people who work with them have different ideas of how they can be used.

We build on two main insights from Penrose. The first is that the (emergence and) growth of the firm does not depend so much on the efficiency with which the firm is able to organize production as it does on the ability to establish one or more "impregnable bases" (or basic position) from which it can adapt and extend its operations in an uncertain world (Penrose 1959/2009, p. 121) and that although there are no limits to the fields of production a firm can enter into, there are limits to the rate it can enter into new fields of production. Material and human resources create the subjective productive opportunity set for each firm. Although there can be a range of objective opportunities open to the firm, their recognition is subjective (Druilhe and Garnsey 2004) and depends on access to specialized knowledge. As firms grow, they accumulate different resources, including human and material resources, and the heterogeneity of those resources means that they can be used in different ways. We draw on this to explore the need of the firm to establish such impregnable bases relying on the subjective recognition of the entrepreneur.

The second is that resources support different "production bases" or "technological bases" in the firm ("each type of productive activity that uses machines, processes, skills and raw materials that are complementary and closely associated in the process of production") (Penrose 1959/2009, p. 97). This means that a move into a new base requires the firm to build competence in a different area of technology. Indeed, the type of productive opportunities chosen influences the entrepreneurial process and resource requirements, including partnerships to access the different resources required to develop and commercialize innovations (Druilhe and Garnsey 2004; Garnsey and Leong 2008). Thus, we seek to explore the technological bases available to the firm and the resource requirements, including partnerships to develop those bases and access the needed resources.

\subsection{Productive opportunities and uncertainty}

We also start from the position that the emergence of firms (and their search and changing productive opportunities) unfolds in a context of uncertainty. Uncertainty is a key concept for much of economic analysis, but one which is used in very different ways by different scholars (Lawson 1988). Here we focus on two seminal contributions from economics that define uncertainty as a situation where the totality of possible outcomes is unknown and the probabilities associated with those that are known are not measurable. The first contribution is that of Knight (1921), who was the first to propose a difference between risk and uncertainty. He argues that risk applies to situations in which both the set of options and their probability distribution over this set are known. Choices under risk can be made by standard (optimal) procedure. No such possibility is open to conditions of uncertainty. As argued by Knight (1921, p. 146), "in the case of uncertainty ... it is impossible to form a group of instances, because the situation dealt with is to a high degree unique." For Knight, uncertainty can be reduced by decreasing these types of situations through grouping ("consolidation") or by selecting people who can bear the uncertainty ("specialization") (such as sciencebased entrepreneurs).

The second is that of Keynes (1921/ 1973), who like Knight regards uncertainty as a situation in which probabilities are not numerically determinate, but unlike Knight does not rely on a binary divide between risk and uncertainty (Lawson 1988). For Keynes, fundamental uncertainty is central to understanding the economy and is not in principle eliminable. Uncertainty is instead endogenous to the structure of the economy and can vary in degree between different groups and over time 
(Dow 2014). Keynes claimed that investment is driven by "animal spirits," and waves of optimistic or pessimistic expectations lead to booms and busts. He recommended that decision-makers compare courses of action in terms of "evidential weight" or absolute amounts of relevant knowledge against "relevant ignorance."

We build on two further insights from economics and management studies of uncertainty. The first is that while uncertainty creates upheaval in the economy, it is a necessary condition for entrepreneurial ingenuity and action. Non-orthodox economists, particularly post-Keynesians, argue that economic actors operate in an ever-changing complex system and the accompanying uncertainty brings threats as well as opportunities. Imagination in the face of uncertainty is a source of novelty. Shackle (1979) and Hay (1980) see the interaction of the entrepreneur/manager's accumulated experience and his/her ingenuity as suggesting various courses of actions (or sets of productive opportunities), each with a plurality of alternative outcomes and different possibilities (not probabilities). In this view, entrepreneurial choice is a creative leap of faith. For Loasby (2002), in such a context, innovating entrepreneurs rely on "connecting principles" of association and causation, on contexts of "incomplete similarity," and category-based judgments of possibility, which differ between individuals in a firm and firms in an industry (and, moreover, may fail).

A second insight is that uncertainty is a multifaceted construct. Beckman et al. (2004) differentiate between firm-specific uncertainty and market uncertainty. Firmspecific uncertainty stems from a variety of sources, including entering a new market, acquiring another firm, turnover in top management, and technical uncertainty, which concerns the likelihood of technical success and the costs associated with that success. Market uncertainty is shared across a set of firms and includes competitive uncertainty (created when the competitive actions of a rival influence a firm), demand uncertainty (which comes from the general level of demand for an industry's products), and input cost uncertainty. In turn, Graffin and Ward (2010) distinguish between technical uncertainty (the degree to which the capabilities of an actor can be inferred over time based on known performance dimensions) and performance standard uncertainty (which does not relate to the quality of the actor's capabilities but concerns the standards or yardstick against which the actor's capabilities are to be judged in order for them to be considered acceptable or desirable). Performance standard uncertainty is argued to give rise to equivocal situations and may stem from two sources: (i) if several performance metrics are available, different decision-makers may have conflicting interpretations of which metric is the appropriate or desired performance standard and (ii) decision-makers may prefer ambiguous standards to maintain control over the assessment process (Graffin and Ward 2010). Although it is not clear whether performance standard uncertainty refers to uncertainty or ambiguity (Ellsberg 1961), this contribution suggests that different types of uncertainty may affect firm emergence.

We thus derive two important insights into the nature and effect of uncertainty on the development of productive opportunities in firm emergence. The first is that uncertainty is not only created by the emergence of new economic structures but can itself be a source of innovation and emergence of new economic structures. The second is that uncertainty is multifaceted and needs to be addressed in a given context of firm emergence by the different organizations involved in decision-making, which may use different types of assessment of the innovator's capabilities to provide the resources required to exploit the productive opportunities.

2.3 Extending the concept of productive opportunities: uncertainty and emergence of science-based firms

We propose an extension of Penrose's concept of productive opportunities in two ways. First, we suggest that by giving greater attention to entrepreneurship in science-based sectors, we can gain deeper insights into the relation between the development of productive opportunities and uncertainty. Penrose's work portrays technology resources as almost versatile or fungible (Nason and Wiklund 2015). Subsequent research from evolutionary economists suggests that knowledge is firm and industry-specific. We think of firm development and search as resulting from a knowledge base or technological base that can expand in new directions. Nevertheless, research demonstrates that leveraging and applying such technology to additional markets is not simple. A firm must build complementary assets to serve those markets (Teece 1986; Tripsas 1997) or "delink" such technology from existing products and re-link to new ones (Danneels 2002).

Science-based entrepreneurship is itself peculiar, as advances proceed along established technological trajectories and technological opportunities are often temporary (Katila and Mang 2003), and those that 
identify opportunities need partners to seize them (Almeida et al. 2003). New firms in science-based sectors face considerable challenges in resolving the uncertainty surrounding the development and production of an innovation due to the long, complex, and emergent scientific and technological advancement they are immersed in. This involves much tacit knowledge and addressing a unique set of interdependent technological and scientific problems (Pisano 2006; von Hippel 1988). Science-based firms are engaged in a unique iterative and inductive process of acquiring and screening information and knowledge, and work at early stages of a technology's life cycle, when technological uncertainty is at its peak (Dosi 1988). Moreover, the uncertainty of science-based entrepreneurship surrounds not only the focal firm itself but also the firm's innovation ecosystem (Adner and Kapoor 2010).

These challenges are compounded by the fact that science-based firms typically resort to venture capital and public equity - two funding mechanisms not designed for R\&D enterprises - as standard accounting mechanisms reflect poorly R\&D portfolios (Pisano 2006). Thus, they are driven to monetize their intellectual property through a corporate partner, but unlike other high-tech sectors, science-based firms' knowledge is not easily tradable; it is complex, involves much tacit knowledge, and is sector-, firm-, and even researcherspecific. Thus, the productive opportunities developed by the firms are in essence the process through which firms restructure their productive opportunities (around certain technological bases) in a context of uncertainty to be an attractive partner for an alliance with another organization.

While innovation collaboration and partnerships have been shown to be very important for innovation success (Hagedoorn and Duysters 2002; Mytelka 1990) and especially for entrepreneurial science-based firms (Powell et al. 1996), there are serious obstacles for science-based firms to engage the needed partners to exploit the productive opportunities they identify. Indeed, the short window of opportunity and the different perceptions about the value of the productive opportunity among firms can impede the process of finding partners to exploit these opportunities quickly (Katila and Mang 2003). This is because tacit knowledge is high in the early stages of development of the scientific advances and firm emergence, limiting the organizations' ability to articulate the knowledge of the opportunity to potential partners.
Second, by focusing on the emergence stage of science-based firms, we provide further insights into the relation between the development of productive opportunities and uncertainty. Firm emergence is characterized by great uncertainty regarding the assembly of resources and the development of new organizational structures and routines, as firms not only attempt to do something new but also suffer from lower reputation and legitimacy to access the required external resources from partners (Hite and Hesterley 2001). In this context, knowledge incompleteness (Dosi and Egidi 1991) precludes decision-making around traditional decision theory (both for the entrepreneurial team and its partners). In the face of innovation, there is not just a lack of the necessary information but also a limitation of the problem-solving competence of actors to frame, recognize or interpret the information and derive a course of action. This is because events become partly endogenous to the decision-making process, with interactions between actions, events, and outcomes (Dosi and Egidi 1991).

An exploration of the emergence of science-based firms can thus offer insights to build on and extend Penrose's concept of productive opportunities by allowing us to probe further into the relation between firm emergence as the development of productive opportunities and uncertainty. We draw on this framework to address the following questions: how and why do entrepreneurial science-based firms emerge through identifying and pursuing their productive opportunities when both their science (and technology) is uncertain and the market for its products or services often does not exist yet? How do they persuade partners to buy in to these productive opportunities to access the external required resources in a timely manner?

\section{Research design}

To understand the emergence of a science-based firm as a function of its productive opportunities, we conducted a longitudinal, single-case study using process research. A process perspective emphasizes the temporal sequence and unfolding of events to explain how something emerges, evolves, or terminates as holistic configurations (Langley et al. 2013). By including time in our study, we capture the unfolding and particular process of how a science-based firm "becomes." This is in contrast to variance-based 
approaches that ignore time but are able to predict that $\mathrm{A}$ is better than $\mathrm{B}$, yet do not necessarily explain how or when A occurs (Langley et al. 2013).

From a process perspective, we view the science-based firm as engaged in a continuous development of its technological bases and construction of partnerships to access and develop the resources required in a context of uncertainty. We regard organizational phenomena not as an accomplished event but as an evolving, unfolding process, in which actors make choices interactively and draw on broader sets of internal and external resources (Tsoukas and Chia 2002). In this way, science-based firm emergence and growth, as a function of the constructive identification and realization of productive opportunities, is an underexplored phenomenon.

Our temporal period of analysis is not demarcated by specific beginning and ending events. We are thus not interested in a performance outcome per se. We subscribe to the view held by Langley et al. (2013, p. 10) that "a process perspective would generally view outcomes such as organizational performance measured at particular points in time as ephemeral way stations in the ongoing flow of activity ... outcomes are probably better understood as inputs that are made sense of in determining further activity." For our study, the identification and realization of productive opportunities is at the same time an outcome of a process and an input for the assembly of resources and development of capabilities to pursue and exploit them.

A longitudinal, in-depth single-case study is appropriate (Balogun and Johnson 2004), as it allows us to delve deep into the interactions of phenomena in complex situations (Dubois and Gadde 2002). Including more cases in our research design would not have necessarily increased the explanatory power of our analysis; in fact, more cases may have reduced the depth of insight. Our research aim called for the examination of interdependent variables, or events and actions, embedded in time and complex structures. A deeper analysis of a single case with embedded sub-cases allowed us to analyze how the productive opportunities change over time and space. This approach enabled us to trace the iterative paths, the trial and error, of an emerging science-based firm and gave us prolonged and deep interaction with the events, actions, and outcomes, as they unfolded in the context of uncertainty. It provided the insight for us to develop more generalized theory on the firm's development of productive opportunities around its technological bases in a context of uncertainty.

\subsection{Case selection and empirical context}

We chose to study a biopharmaceutical firm as a revelatory case (Yin 1994), reflecting a real-world, real-time situation. We gained access to the new venture from our prior relation with the founder when he was employed at the parent company. He informed us of his intention to start a new firm, and we commenced data collection in 2013, after his required period of garden leave.

In line with prior contributions (Rasmussen et al. 2011; Vohora et al. 2004), we consider that the firm has emerged as it has passed an important credibility threshold in terms of both adding new team members beyond the original founder and gaining early stage investment from private sector investors. We followed the venture from its origin to passing this credibility threshold, and we continue to follow the venture in real time.

The new venture, BioCure, ${ }^{2}$ is a spin-off from an established biopharmaceutical firm in Manchester, UK. The founders of BioCure, John and Sarah, were prior colleagues and were both experienced scientists with complementary expertise. BioCure was founded with the purpose of developing and commercializing potential technology underutilized by the parent company. BioCure therefore started with an initial set of scientific and technological knowledge, and possible productive opportunities, based on the molecular profiling and growth of stem cells. The aim of the venture was to develop and outlicense candidates for novel stem-cell therapeutic drugs in the targeted areas of oncology and regenerative medicine.

\subsection{Data collection}

Deep probing of single cases requires data collection from multiple sources of data (Yin 1994). Our primary sources of data included semi-structured interviews and company documentation. As our case is a new venture, data from historical archival documentation or third party accounts of the firm were limited. We were given access to documentation that BioCure produced or

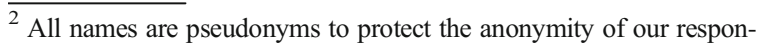
dents and their collaborators.
} 
received from various actors such as investors, large pharmaceuticals, university research departments, and lawyers. Due to our regularly scheduled interviews, we were privy to the making of BioCure's organizational history and captured the evolution longitudinally in real time. In this sense, our data is a historical record.

We held regularly scheduled semi-structured interviews approximately every 4 to 6 weeks, totaling 37 interviews over a 4-year period (see Table 1). These interviews followed a semi-structured questionnaire, looking back on the past month's activities and forward to goals and activities of the coming month. Each interview covered the progress of research and development activities and commercial orientation and access and assembly of three specific types of resources: technological development, fundraising, and operations. The duration of the interview meetings varied between 90 and $120 \mathrm{~min}$. Both researchers conducted the interviews to ensure continuity from one interview to the next, discussion of progress, and agreement on areas of focus in subsequent interview meetings.

The majority of the semi-structured interviews were held with one founder, John; however, in the first year, we held four interviews with both founders, John and Sarah (after which Sarah left the firm). As we progressed, John became increasingly candid and used the meetings as a way to "think out loud." Occasionally, he sought our advice, for example, on the business proposition or on how his process compared to others. We were cautious to be supportive and to provide a sounding board, on the one hand, but on the other not to interfere with the data collection. ${ }^{3}$ The founder was unaware of our theoretical expectations. He had read our prior work and knew that we were interested in the resource acquisition of emerging science-based firms. His candor was rooted in a genuine desire to help us understand science-based firm emergence and more personally in the reflexive practice of analyzing past events. Interviews were audio recorded and transcribed verbatim.

We also had complete access to all associated company documentation, including (i) written correspondence

\footnotetext{
${ }^{3}$ Our method is not intended to be action research, which involves four iterative and repetitive stages, including planning, acting, observing, and reflecting (Lewin 1946). In action research, researchers become participants (Melrose 2001), anticipating changes and developments that affect activities, learning, and outcomes, and making adjustments or using techniques to steer actions and decision-making. Although we continue to have regular interviews that encourage reflection, as researchers we do not participate in the actions of BioCure's emergence and development.
}

(memos, emails, letters) to and from potential partners, customers, and investors; (ii) contractual agreements drafted by lawyers; (iii) drafts and revisions of the business plan; (iv) presentations to investors and potential partners; and (v) financial documents and annual returns. Moreover, we had access to BioCure's internal project management system and followed internal messaging on planning, managing, and communicating about various business, technology, partner, or fundraising leads. Table 1 provides an overview of the data sources.

The multiple sources of data helped to triangulate the evidence and establish reliability. Considering that our case is a new venture with limited respondents, we relied on documentation from potential partners and investors to provide additional perspectives and to understand the context more fully. The unit of analysis is not the case itself but rather the productive opportunities that we identified from events and activities (Langley et al. 2013). We validated interpretations of these activities through triangulating the data from these different sources.

\subsection{Data analysis}

Our analytical approach was primarily abductive, as we continuously iterated between research activities and between theoretical and empirical observations (Dubois and Gadde 2002). Although our theoretical framework provided, deductively, a guideline for our analytical constructs, it evolved inductively as we discovered emergent themes and insights from our fieldwork and data (Strauss and Corbin 1997). Based on prior work, we structured our interviews to gather data about access and development of three critical resources for science-based firms: technological, managerial/operational, and financial resources. This structure provided consistency and focus to our data collection. As we proceeded, we gained a greater empirical understanding of the interactions with potential partners and the associated types of uncertainty and responses to such. This empirical understanding helped us to adjust our theoretical preconceptions, which in turn shaped our subsequent empirical observations. This systematic and iterative process was an essential part of our data collection and analysis.

The interview data were transcribed and the transcripts and company documentation were coded for events, activities, and definitions (Gioia et al. 2013). We developed an initial coding template in January 
Table 1 Overview of data sources (per year)

\begin{tabular}{|c|c|c|c|c|c|c|}
\hline & 2013 & 2014 & 2015 & 2016 & 2017 & Total \\
\hline Number of interviews & 2 & 10 & 11 & 9 & 5 & 37 interviews \\
\hline Number of documents & 0 & 33 & 57 & 44 & 15 & $\begin{array}{l}149 \text { documents } \\
950 \text { pages }\end{array}$ \\
\hline Emails, memos, correspondence, agendas & 0 & 10 & 31 & 13 & 5 & 371 pages \\
\hline Strategy presentations, business plan & 0 & 6 & 7 & 1 & 1 & 213 pages \\
\hline Project proposals, presentations & 0 & 1 & 1 & 4 & 4 & 164 pages \\
\hline $\begin{array}{l}\text { Fundraising documentation (terms, valuations, applications } \\
\text { for investor events) }\end{array}$ & 0 & 1 & 7 & 4 & 0 & 55 pages \\
\hline Financial reports, annual returns, investor updates & 0 & 1 & 0 & 8 & 4 & 57 pages \\
\hline Presentations from potential partners & 0 & 0 & 2 & 0 & 0 & 48 pages \\
\hline Meeting minutes, action items & 0 & 6 & 0 & 0 & 0 & 10 pages \\
\hline Tracking documents for business development, fundraising & 0 & 0 & 4 & 1 & 0 & 6 pages \\
\hline Planning, Gantt charts & 0 & 4 & 0 & 0 & 0 & 4 pages \\
\hline Mindmaps & 0 & 4 & 1 & 0 & 0 & 5 pages \\
\hline Profiles of potential partners & 0 & 0 & 3 & 1 & 0 & 4 pages \\
\hline Press articles of BioCure & 0 & 0 & 1 & 1 & 0 & 2 pages \\
\hline Scientific publications & 0 & 0 & 0 & 0 & 1 & 1 page \\
\hline
\end{tabular}

2015, around the time of interview \#12. We coded data related to technology resources (for example, programs, partners, knowledge, and diseaseorientation) and financial resources (such as investors, meetings, and valuations). Each author coded the initial interviews separately, and then we compared and discussed the results of our coding, eliminating, collapsing, or adding codes as appropriate. As we proceeded with data collection, we discussed the evolving coding template and conducted several iterations. Our coding led us to aggregate concepts (such as those related to resources, technologies, uncertainty, and partnerships), and subsequently we used those as constructs to identify productive opportunities and guide our analysis (Gioia et al. 2013).

We used various analytical techniques in analyzing our data, including (i) development of chronologies of events or temporal sequencing, (ii) development of narrative summaries, (iii) identification of first and second order concepts and themes, and (iv) development of key explanatory constructs. We explain each in turn.

As we collected data, we developed chronologies of events (Langley 1999). Figure 1 provides a timeline of the major events that took place during data collection. These chronologies allowed us to develop temporal brackets that demarcated qualitative changes in the progression of events. We identified two distinct temporal brackets based on two different technological bases (or platforms) - a mouse model and a human-tissue model-that marked definitional periods of productive opportunities for BioCure.

Concurrently to the temporal sequencing, we created thick narratives that summarized the temporal events. These narratives gave us a more detailed understanding of the interrelation of the events and context and what type of organizations and actors and when they were involved (Brown 2006; Pentland 1999; Van de Ven and Poole 2005). From the combined analyses of temporal sequencing and narratives, and within the two technological bases, we identified six productive opportunities associated with the technologies. We categorized salient characteristics of each productive opportunity, including the time period (an approximate start and end date), the disease orientation, the technical/ market rationale, the external partners required to access the required resources (financial, scientific, operational), and the outcome. Table 2 summarizes this information on the productive opportunities.

The analysis of the temporal sequences and narratives illuminated the evolving and changing nature of the productive opportunities of the firm 


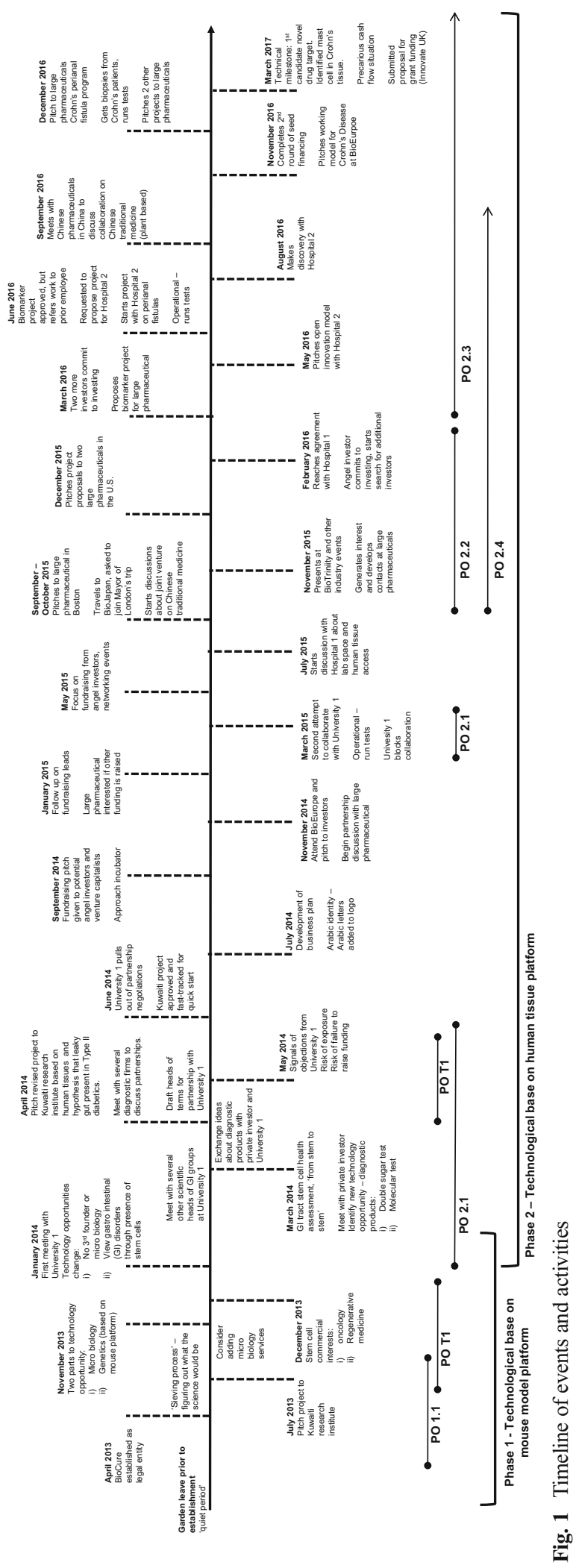

around its technological bases. We began to interpret how the different organizations and actors perceived the productive opportunities and how the uncertainty associated with them manifested. These insights were incorporated into our subsequent data collection and analysis.

Having identified and categorized productive opportunities, we returned to the coding scheme, making adjustments and continuing to code interview transcriptions. We augmented our coding template with concepts and themes on uncertainty. As there were recursive cycles of productive opportunity construction, the different sources of uncertainty and the mechanisms to address it became more apparent. As BioCure evolved, the number of organizations and actors involved in productive opportunity construction and resource acquisition increased, and we had access to a growing volume of documents and correspondence. We coded data from these sources and added the insights gleaned from these to the narrative analysis. Between interviews \#12 and \#28, we aggregated iteratively the coding template, creating second-order themes from the first-order coded concepts (see Fig. 2) (Gioia et al. 2013). This allowed us to progress from the descriptive surface observations to more abstract process theory development.

Finally, we developed key explanatory constructs (or aggregate dimensions) (Corley and Gioia 2004) of access to resources, uncertainty, and mechanisms to address uncertainty, to analyze the development of productive opportunities and science-based firm emergence. Although we present our analytical approach as rather consequential, in reality this was hardly the case. We cycled through our data several times as we identified emergent patterns and themes that constituted these constructs and the interrelation between them.

\section{Findings: development of productive opportunities and uncertainty}

The productive opportunities unfolded subjectively and contingently based on events, activities, and actions that coalesced at particular times. To present our findings concisely, we draw on two contrasting productive opportunities, PO 2.1 and PO 2.3 (see Table 2). These two productive opportunities belong to the second 
Table 2 Overview of productive opportunities

\begin{tabular}{|c|c|c|c|c|c|c|}
\hline \multirow{2}{*}{$\begin{array}{l}\text { Productive } \\
\text { opportunity } \\
\text { characteristics }\end{array}$} & \multirow{2}{*}{$\begin{array}{l}\text { Phase } 1 \text {-mouse } \\
\text { model technology } \\
\text { platform } \\
\text { PO } 1.1\end{array}$} & \multirow{2}{*}{$\begin{array}{l}\text { Transition- } \\
\text { combination } \\
\text { PO T1 }\end{array}$} & \multicolumn{4}{|c|}{ Phase 2-human-tissue technology platform } \\
\hline & & & PO 2.1 & PO 2.2 & PO 2.3 & PO 2.4 \\
\hline $\begin{array}{l}\text { Disease } \\
\quad \text { orientation }\end{array}$ & $\begin{array}{l}\text { Gastro-intestinal } \\
\text { diseases }\end{array}$ & Diabetes & $\begin{array}{l}\text { Inflammatory bowel } \\
\text { diseases (IBD) }\end{array}$ & $\begin{array}{l}\text { IBD, cancer, } \\
\text { biomarkers }\end{array}$ & Perianal fistulas & $\begin{array}{l}\text { Traditional } \\
\text { Chinese } \\
\text { medicine }\end{array}$ \\
\hline Start-end date & $\begin{array}{l}\text { April to November } \\
2013\end{array}$ & $\begin{array}{r}\text { May } 2013 \text { to } \\
\text { May } 2014\end{array}$ & $\begin{array}{l}\text { December } 2013 \text { to } \\
\text { June } 2014 \text { and } \\
\text { March to April } 2015\end{array}$ & $\begin{array}{l}\text { July } 2014 \text { to } \\
\text { June } 2016\end{array}$ & June 2016 ongoing & $\begin{array}{l}\text { October } 2015 \text { to } \\
\text { December } 2015 \\
\text { August } 2016 \\
\text { ongoing }\end{array}$ \\
\hline $\begin{array}{l}\text { Technical } \\
\text { rationale }\end{array}$ & $\begin{array}{l}\text { Track record of } \\
\text { using mouse } \\
\text { models }\end{array}$ & $\begin{array}{l}\text { Hypothesis that } \\
\text { diabetics have } \\
\text { compromised } \\
\text { gut }\end{array}$ & $\begin{array}{l}\text { Advantages of human } \\
\text { model (closer to } \\
\text { patients) }\end{array}$ & $\begin{array}{l}\text { Advantages of } \\
\text { human model } \\
\text { (closer to } \\
\text { patients) }\end{array}$ & $\begin{array}{l}\text { Advantages of } \\
\text { human model } \\
\text { (closer to } \\
\text { patients) }\end{array}$ & $\begin{array}{l}\text { Advantages of } \\
\text { human model } \\
\text { (closer to } \\
\text { patients) }\end{array}$ \\
\hline $\begin{array}{l}\text { Market } \\
\quad \text { rationale }\end{array}$ & $\begin{array}{l}\text { GI oncology } \\
\text { market }\end{array}$ & Diabetes market & $\begin{array}{l}\text { Market for GI disease } \\
\text { diagnosis, } \\
\text { prevention, and } \\
\text { treatment }\end{array}$ & GI diseases market & GI diseases market & GI diseases market \\
\hline $\begin{array}{l}\text { Required } \\
\text { critical } \\
\text { resources } \\
\text { - Financial } \\
\text { - Operational } \\
\text { - Scientific }\end{array}$ & $\begin{array}{l}\text { Microbiology } \\
\text { expertise }\end{array}$ & $\begin{array}{l}\text { Financing } \\
\text { Technology } \\
\text { validation } \\
\text { Human tissues }\end{array}$ & $\begin{array}{l}\text { Human tissues } \\
\text { Clinical knowledge }\end{array}$ & $\begin{array}{l}\text { Financing } \\
\text { Technology } \\
\text { validation }\end{array}$ & $\begin{array}{l}\text { Financing } \\
\text { Technology } \\
\text { validation }\end{array}$ & Financing \\
\hline Partners & $\begin{array}{l}\text { Large } \\
\text { pharmaceuticals }\end{array}$ & $\begin{array}{l}\text { Diabetes institute } \\
\text { in Kuwait }\end{array}$ & $\begin{array}{l}\text { University } 1 \\
\text { Research Institute A } \\
\text { Institute }\end{array}$ & $\begin{array}{l}\text { Large } \\
\quad \text { pharmaceuticals }\end{array}$ & Hospital 2 & $\begin{array}{l}\text { Chinese } \\
\text { pharmaceutical } \\
\text { University } 2\end{array}$ \\
\hline Outcome & Abandoned & Abandoned & Blocked & Abandoned & $\begin{array}{l}\text { Commenced and } \\
\text { ongoing }\end{array}$ & Negotiating \\
\hline
\end{tabular}

technological base (the human-tissue technology platform). ${ }^{4}$ PO 2.1 is exemplary because it occurred early in the process of emergence, involved several actors, and introduced the technical/market rationale that shaped ensuing opportunities. PO 2.3 was the productive opportunity that was realized. By focusing on these two productive opportunities, we do not imply that they happened in isolation from the other productive opportunities that BioCure was pursuing.

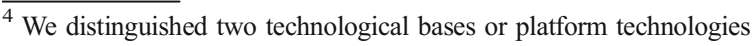
(see Figure 1). The first, based on mice, enabled the founders to build on and extend the technology and capabilities that were inherited from the founders' prior employer. The technical rationale for this technology platform was based on the prior track record of mouse models in oncology supportive care (e.g., gastro-intestinal problems due to toxicity from chemotherapy). The second, based on human tissues, represented a major change in the technological base and affected profoundly the formation of the firm. John explained this as "a game changer because that is the preferred tissue [and] it opens up different vistas of business opportunities."
}

\subsection{The gestation of productive opportunities}

PO 2.1, which began in December 2013, focused on developing treatments for inflammatory bowel disease (IBD). ${ }^{5}$ It involved several organizations and actors, but it started with interactions between BioCure's two founders and key scientists at Research Institute $A$ at University 1 in London. It was pivotal as it enabled the founders to reframe the narrative of the company as they envisioned unlimited access to human tissues. John explained, "we could go straight up into a human model. The reason why that is so compelling and exciting ... is that every patient is a pairwise analysis."

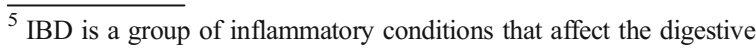
tract, mostly the colon and small intestine, and includes Crohn's disease and ulcerative colitis.
} 


\section{$1^{\text {st }}$ order concepts}

\section{$2^{\text {nd }}$ order themes}

Fundraising from investors / Funding / Alliances with pharmaceuticals

Access to scientific knowledge / technological resources

Securing lab space and equipment, hiring technicians
Aggregated (explanatory) constructs
Direct and indirect ties to investors Company valuation

Prior founder experience / knowledge Common traditions, shared experiences/understanding Complementary knowledge (external)

Location advantages

Contingencies of partnerships Recruitment - skills required Business proposition, market opportunity

dge

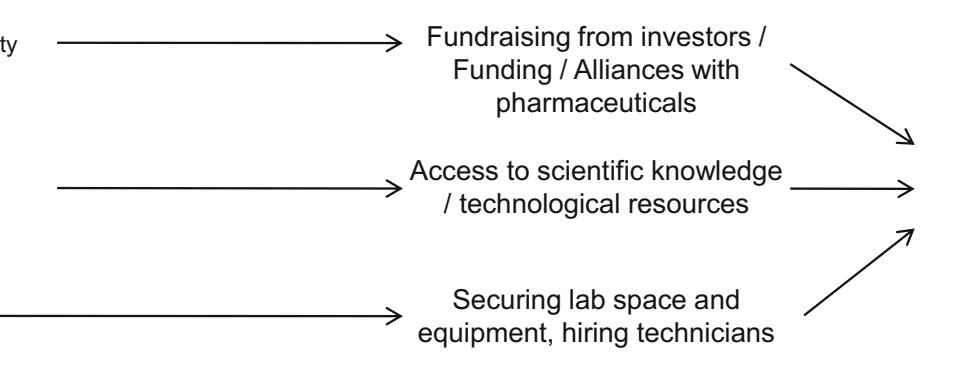

Feasibility / promise of science, scientific program Capabilities of founders, management team Recognition of opportunity Coordination problems, governance

Identifying, anticipating obstacles for 'buy in' Establishing credibility, trust, signaling Environmental scanning and change

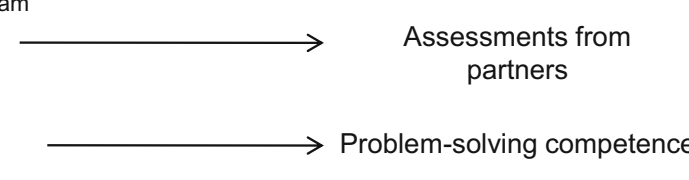

Assessments from partners

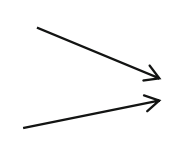

Context of uncertainty

\author{
(Changing) Narrative around productive \\ opportunities \\ Information gathering to assess uncertainty \\ Consultation with experts, partners \\ Interpretations of environment, growth expectations
}

Outcome of resource acquisition efforts

Order of acquired resources

Type of acquired resources

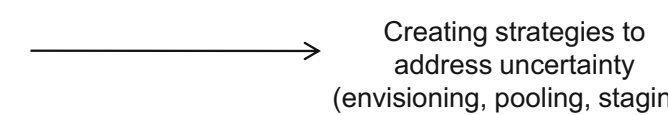
(envisioning, pooling, staging)

Temporal sequence of resource acquisition
Assembly of

internal and

external

resources

Fig. 2 Coding template of data structure: analytical concepts, themes, and constructs

BioCure developed significantly its scientific program during the period of PO 2.1. A flurry of activity in the first months defined the scientific program in conjunction with Research Institute A's key scientists. They envisioned PO 2.1 to encompass a range of services and products. It was described in narrative terms, such as "stem to stern" or "sausage factory" to depict the products and services offered at various stages of gastro-intestinal (GI) disease diagnosis, ${ }^{6}$ prevention, and treatment. This included personalized medicine, predictive diagnosis, and stem cell therapies. This full range of products and services based on a human tissue

\footnotetext{
$\overline{{ }^{6} \text { Other potential }}$ partnerships were also pursued simultaneously to realize a diagnostic product. These partnerships were envisioned as strategic alliances or joint ventures with small biotech firms. Given the lack of experience and knowledge in developing and producing a diagnostic product, these additional partners were essential to pursuing the diagnostic element of PO 2.1. But the enthusiasm for these partnerships and diagnostic product development waned and the partnerships never materialized.
}

technology platform shaped the pursuit of productive opportunities subsequent to PO 2.1.

To exploit PO 2.1, BioCure sought a partnership with University 1 and its Research Institute A to access critical technological resources, namely human tissues from biopsies and GI clinical expertise. As the scientific negotiations progressed, Research Institute A scientists voiced various concerns and requirements. BioCure conceded to all of their requirements, which John explained as "removing the obstacles" and saw the concessions as acceptable for a long-term, mutually beneficial partnership.

Once the scientific program was determined through iterative discussions with key scientists, representatives from University 1's technology transfer office (TTO) became involved in the negotiations. As we explain below, the collaboration with University 1 came to a halt in May 2014 because the TTO had concerns about the viability of BioCure, asking for an equity position and/or that BioCure raise external financing before agreeing to collaborate. 
Several months later, in February 2015, the opportunity to collaborate with University 1 through another department, the neurogastroenterology group, and a large Japanese pharmaceutical firm appeared. In March 2015, BioCure became operational for 2 weeks, hiring temporary technical staff and conducting initial tests, until the TTO again halted the collaboration. Up to December 2015, John continued to search for other partners (primarily large pharmaceuticals) to pursue PO 2.1, based largely on the same scientific program.

In contrast, PO 2.3 arose in June 2016 somewhat serendipitously. Whereas in PO 2.1 the sequence of resource acquisition started with further development of the technological resources, in PO 2.3 John placed emphasis on securing access to other resources. In the interim period between PO 2.1 and 2.3, BioCure engaged in extensive fundraising activities and secured initial seed investment of $£ 150 K$. Simultaneously, he secured operational resources, renting lab space at Hospital 1, procuring equipment, and hiring a lab technician. The further development of the technological resources followed.

Once BioCure was established at Hospital 1, John was asked to engage in "Grand Round" presentations at the adjacent Hospital 2. He expressed his surprise at discovering Hospital 2 had important gastro-intestinal (GI) expertise, “don't know why I didn't know that ... Hospital 2 was a GI hospital." BioCure was asked to collaborate on a project on perianal fistulas. ${ }^{7}$ Initially, the technical rationale to pursue PO 2.3 was weak, but John saw it as a way to establish proof of concept, which, as we will explain below, had proven to be an obstacle for persuading large pharmaceuticals to collaborate on projects. The unmet medical need or "therapeutic opportunity," and a potential market of $\$ 2$ billion, were also convincing. The collaboration with Hospital 2 became BioCure's first collaborative project. Shortly after it commenced, the collaborative team made the discovery that the cells in anal tissue had a different composition than cells from intestinal tissue. Although the discovery would not have much commercial value for BioCure, it had academic value for Hospital 2 scientists and resulted in a scientific publication.

\footnotetext{
${ }^{7}$ Perianal fistulas are a complication associated with Crohn's disease. They are essentially "tunnels" that develop between the intestine and rectum or anus.
}

From the above account of PO 2.1 and PO 2.3, we see that the temporal sequence of resource assembly interacted with the positive or negative outcome of productive opportunity realization. In PO 2.1, the emergent firm developed its technological resources (human tissues and various GI expertise) first. Operational resources (lab space, technicians, and clinicians) were contingent on the development of its technological resources. The limited financial resources created a perceived lack of credibility for University 1, which BioCure could not eliminate satisfactorily. In contrast, the development of PO 2.3 occurred after the assembly of financial and operational resources. BioCure secured financial resources based on the scientific program from PO 2.1 (albeit slightly modified) and, in turn, this allowed it to assemble operational resources. When the opportunity to collaborate with Hospital 2 on perianal fistulas arose, BioCure was able to respond quickly and PO 2.3 was realized.

\subsection{Uncertainty surrounding productive opportunities}

As we followed the different productive opportunities, we began to see that uncertainty was rooted in knowledge incompleteness and problem-solving competence gaps of the emergent firm and its potential partners. We present our evidence on how this uncertainty manifested and the three mechanisms that emerge from our analysis - envisioning, pooling, and staging - that were used to address it.

Uncertainty was apparent and pervasive and was reflected in the usual request by all of the potential partners for better "proof of concept" or more "baseline data" from the technology platform. Many of these partners refused to commit resources to the new venture until their requests were met. This led to a "catch 22 " situation, in which BioCure aimed to enter a collaboration with either a university or pharmaceutical firm to generate data, but the partner requested to see more data first before agreeing to collaborate. The founder expressed frustration regarding these requests for more data, taking them "with a grain of salt." John explained that large pharmaceutical firms "always ask for more data" and expressed his skepticism about defining criteria for such further studies and suggested instead that it would be more productive to test the pharmaceutical firms' compounds. 
The persistence of this uncertainty hindered the development of the productive opportunities in a recursive pattern. Leads from trade fairs and networking events for both financial resources and business development were plentiful but resulted in similar requests for baseline data, as evidenced by the following excerpts from emails from large pharmaceutical firms:

[our] research would like to see more data before committing to investment ... we do need support from [our research unit] to go forward with seed fund investment and it is just not there ...

The build [discovery platform] is really impressive, supported by sustained access to patients, but we need a few case studies [baseline validation] before continuing discussions.

Uncertainty also manifested in the way partner organizations used different assessments to judge BioCure's capabilities. In PO 2.1, there were various groups from University 1 that were engaged at different stages and they used varying assessments, which contrasts with the simpler assessments in PO 2.3. From our data, we identified three different forms of assessment - scientific, legal, and reputational - that were used (often simultaneously) by the partner organizations. All of these simultaneous and often conflicting forms of assessment reflected the limitations on the problem-solving competences of potential partners to frame and interpret the innovator's capabilities, compromising their buy in. We show evidence of use of each form of assessment.

In PO 2.1 and 2.3, the assessment of science capabilities and skills and the likelihood of success of the scientific program were scrutinized in meetings and presentations with scientific peers. The process of scientific assessment in the case of PO 2.1 was complex. There were many scientific meetings and brainstorming sessions with different groups of scientists at University 1 to "identify some central themes." The areas of common scientific interests snowballed, as explained by John:

...[At] University 1 there are four or five disease area groups that we are looking to engage with. There is inflammatory bowel disease, oncology, diabetes, ageing ..., hypermobility syndrome, oesophageal reflux [oesophagitis].

John gave several indications of the scientific assessment that took place through the tough questioning and demands. For example, he explained, "the IBD guy ... was quite abrasive." He described another scientist as "the old school [type], telling me ... that [he is] one of the top ten people in [his] field."

In contrast, the scientific assessment of PO 2.3 was quick and simple. John gave a "one hour Grand Round presentation." The number of scientists involved in the scientific assessment was limited. The response from scientists at Hospital 2 was "very enthusiastic" and in a follow-up meeting, the founder and the dean of the academic institute agreed to develop an open innovation collaboration. Shortly thereafter John received a request for a specific project proposal, which was approved.

We see that in conjunction with the assessment of scientific capabilities, other forms of assessment were introduced, namely legal and reputational. It is difficult to untangle the timing in the use of these forms of assessment, and in PO 2.1, there is evidence of an iterative and recursive pattern. In PO 2.1, a legal form of assessment was introduced into the scientific discussions early on as a two-way confidential disclosure agreement was signed to facilitate the exchange of more detailed scientific knowledge. Three months after scientific discussions started, many questions about legal implications emerged. Action items and documentation from a meeting at the end of March 2014 showed the start of a broader legal evaluation. An action list showed the following item: "what is University 1's policy on tissue ownership?" indicating concern for potential liability. Another item, "does tissue definition change when processed, in particular establishing crypt organoid cultures?" implied boundary parameters for potentially new intellectual property challenges arising from the collaboration.

To address these rising legal considerations, John prepared a memo that prioritized the issues, including intellectual property, tissue ownership, and lab space. He established his credibility by explaining his previous experience in intellectual property and licensing arrangements. At this point, John consulted a law firm, which later wrote the "heads of terms." John elaborated on the boundaries of intellectual property inventorship and business terms:

The process starts by each party defining 'background knowledge' which includes core competences and invention disclosures at the outset of the collaboration. Invention disclosures are 
submitted to the collaboration's patent counsel throughout the collaboration. When filing patent applications, the collaboration's patent counsel will assess each person's contribution to the invention - regardless of their affiliations - to make a determination on inventorship.

Inventorship rules would determine the business terms, and he elaborated:

They might have interest in the patent but whatever deal they have with the university is their deal $\ldots$ If ... they get [10\%], I don't care. It deals with the university. If they have a problem with getting paid, we say, talk to your university.

The memo outlined BioCure's position on the issue of tissue ownership. He anticipated "generating a large bank of intestinal organoids and other tissue stem cells" which would be used in the collaboration but also used separately by each party freely. Tests would be done on the university premises. But concerning tissue ownership, John was rather indifferent:

I don't really care if we own them, just as long as we have restricted use. ... We use it for our internal programs, R\&D only, with them, and with pharma. We would not sell the tissues ... once we get these hundreds of samples and get this bigger picture, we will probably never look at those samples anyway.

Furthermore, the cost of tissue ownership was a concern. This was not specifically mentioned in the memo but John elaborated:

if they own the tissues... then they can pay for storage. ... we don't want to be responsible for that. ... it's not an area to 'go to the mat' and be ugly over, especially if you realize that once you got the tissues and have that original discovery, you don't really need them any more.

The issue of tissue ownership was not a trivial matter, and agreeing to have lab space at University 1 was a way to abate some of the concerns. This became a requirement for proceeding with the collaboration. The demands placed on BioCure during the scientific assessment included renting lab space, hiring a clinical nurse, and funding PhDs. This phase of legal assessment closed with BioCure requesting a "material transfer agreement" so that they could determine whether they could "get stuff done." Nevertheless, another form of assessment was simultaneously at work and impeded progress, namely, reputational assessment.

This form of assessment was most apparent in the collaboration with University 1 in PO 2.1. The nature of the collaboration with University 1 seemed to be surrounded by more uncertainty for all the partners. Once legal assessment began, more actors within University 1 became involved in the negotiations, namely business development managers from the TTO. John's reaction to the first encounter with one of these managers was cautiously positive and emphasized the mutual benefits of the partnership:

If it is presented as a win-win situation ... I think that will fly. If you start hyping that and saying these human tissue samples could lead to a cure for this disease, then people will start to say, I want to be compensated for that. ... [It needs to be] very clear that we're in this game together and that there is a mutual benefit.

Nevertheless, the tone of the negotiations changed abruptly when another business development manager entered the negotiations:

... what she did in that meeting was mark her place in the discussion ... It went from an IP [intellectual property] discussion to a general business discussion. ... we were here to talk about IP, the process of doing this and the licensing terms. All she wanted to talk about was the business model ... she said, 'you guys are the middlemen, you are going to pharma ... We're the clinicians, you're the middleman.

John noted the reservations of University 1's business development manager and was concerned that BioCure was being undervalued:

... we are the ones that make the discoveries that translate this to the other people. You guys aren't going to do this. You're not stem cell experts, you're not biotech people.

Still, University 1's business development manager was not fully satisfied and continued to make more requests, stating that they required "[making] an investment in the company" and then a request for an equity position instead of an investment because the 
manager believed BioCure "would be raising money on the back of University 1." The abrupt turn towards a reputational assessment surprised John and Sarah:

We are a young company with no assets. So I said what is the exposure?... I suppose the reputation. [They] are putting no money in. [It's a] marginal increase of time to take out a couple of extra biopsies. We are processing them with a couple of FTEs [full time equivalents] and we are consulting with [them]. So where is the risk? It is primarily reputation. They do not want to be involved in anything that is deemed risky. We could have an agreement and then we [might not get] the funding and then what would happen? ... it would simply be public knowledge that they had a failed engagement.

The reputational scrutiny from University 1 resulted in greater uncertainty for BioCure. In order for University 1 to discuss internally the possibility of pursuing the collaboration, the business terms needed to be defined. Yet, there was no agreement on business terms. Moreover, due to these protracted negotiations, John and Sarah began to question the competence of University 1 as a potential partner. Prior to these negotiations, they spoke positively of the professionalism at University 1, "really textbook type of communication ... I'm very impressed." When the discussions moved to negotiating business terms, their opinion changed:

... when we moved on the heads of terms ... they were dismissive, like we ... low-balled and were really unreasonable.. I don't think [University 1] has much experience.

Also, the founders experienced uncertainty and lost confidence in the ability of the head of the Research Institute A to champion the collaboration internally:

Our contact had a meeting with the business manager and it's completely gone off the rails ... Literally everything we talked about was shot down ... [we] understand that he is not a business person. But for him to be so inflexible is a little puzzling ... I don't know how much of the actual conversation that happened behind closed doors is accurately reflected to us.
Having met successfully the scientific assessment, the urgency to remove the concerns associated with reputational assessment was high. Although the founders were keen to "figure out a pathway forward with University 1 the business development manager was not swayed:

[our contact] couldn't imagine a way to go forward ... [he] tried everything and tried to explain it, but ... it sounds like they won't do anything without [BioCure] getting the funding first.

Negotiations came to halt. BioCure would have to raise funding before the collaboration could take place, but also the new demand from University 1 of owning $50 \%$ of the company would outstrip any benefit of collaborating with University 1 for BioCure.

\subsection{Mechanisms to address uncertainty}

Our data showed that the founder employed three mechanisms to address uncertainty in the different productive opportunities: envisioning, pooling, and staging. John employed these mechanisms strategically at different times or simultaneously.

From the start of the venture, he was continuously envisioning the different future states or scenarios of the emergent firm. In the interviews, there were verbal cues of these scenarios, such as "it's a different story,...," "you really have to think that through, if ...," or "this is the way it will work,..." During the pursuit of PO 2.1, the founder used elaborate scenarios, which provided the basis for the narrative that persisted through subsequent productive opportunities. The following illustrates the initial vision of the collaboration with University 1:

Here is what happens. They give us tissues, whether they are biopsies or resection tissues, and we take the tissues and we grow up the stem cells in our cultures. We can tell them whether the stem cells are normal or abnormal. Right, if they are abnormal then we can do whole genome sequencing. We could do a number of tests, we can look at dose response of drugs, and we could find out what kills specifically that diseased stem cells and not the healthy stem cells. Or if we take the tissue, we put it in, and their stem cells are fine, then they don't have a stem cell disease. [If] they are all bad, then the only alternative is stem cell therapy, which is still very far away. So in the meantime, they get to 
learn, is it a stem cell disease, yes or no? If it is a stem cell disease, what is the gene defect? We write them a report, we develop what that report is, a lot of functional studies, we will be doing immune studies and characterizing them. Then ... what do we get as BioCure? We get, first, a highly motivated team, technicians, who are going to be giving information that is going to be informing clinical decisions. That is pretty rare. The second thing is that as we build our bank we take that asset and we go to pharma and we are looking for drugs that kill those specific human conditions. We have a panel of ten or twelve, however many we have over time, and we can screen their compounds and optimize these compounds on these tissues. They'll have case reports and ... we identify drug candidates...

This early envisioning helped the founder develop the narrative he used to get the potential partners motivated about the collaboration and to identify the services of knowledge exchange (e.g., clinical diagnosis, reports) that BioCure could offer University 1 while at the same time advancing BioCure's research and development of therapeutic treatments. The founder's envisioning was also very detailed in working out the terms of intellectual property. He envisioned the mechanics of inventorship as follows:

... you start off with the collaboration, you record all the background information, what you knew at the time you started, including the potential inventions, and that sets the base. And then you go forward and you collaborate. As you make inventions, we report them to the attorneys and invention disclosures and when it becomes time to write the patent applications and to identify the inventors, the attorneys are the ones who do that. It's not authorship, there is no pressure; they look and see who contributed to it. Clearly there is scope for adding people on because you want to be nice. Once that gets set, the inventors will be all BioCure or all University 1 or both. You try to give them assurances; it's going to be mostly both on a lot of this stuff. You're in a meeting and somebody picks up on an idea. We know nothing about the gastrointestinal track; [we] are experts in stem cells, so we have advantages there. The most important thing is to get the invention. ... the next step is the business issues. There are standard business issues for sole or joint IP. The terms of all that [are decided] in advance and ... you never have to talk about them again. Done. I think that gave them a lot of reassurance.

The above quotation shows the founder's envisioning as a deliberate mechanism to address uncertainty through helping partners to frame and interpret the information and make a decision to collaborate. For example, when we questioned the founder about the conflicts regarding academics' incentive to publish papers, he envisioned a solution:

We just have a normal disclosure period. You don't actually have to file [patents] until the paper has been accepted, I think, because technically it is supposed to be confidential when it is being reviewed, but we may do it earlier. Depends on what the invention is.

He developed clear scenarios of the division of labor and stated "you [the university academics] write the papers, we write the patents. We are going to be focused on filing patents, managing IP, managing the business."

Envisioning was also used with potential investors to address uncertainty and establish greater confidence in the likelihood of the venture's success. Nevertheless, investors were also concerned about uncertainty arising from lack of "proof of concept" and cited the early stage of the technology as the most common obstacle for not investing. As BioCure developed, envisioning manifested in the pitches presented to potential partners and investors, which culminated in a concise and powerful 7-page presentation: "my thinking evolved ... probably the best presentation I've ever given." Thus, envisioning helped address uncertainty for some partners but not for others, like investors, for which this did not provide sufficient "weight of evidence" by itself to increase confidence.

In addition to envisioning, the founder engaged in what we term pooling, seeking to bundle support for productive opportunities. The pooling mechanism manifested in different ways. First, John pooled advice from various experts whose opinion he trusted. In the early period of the firm, he met regularly with a trusted advisor, a board chairman of the parent firm ("we have known each other for a long time, have gone through hell and high water together"). He described him as "holding his cards close to his chest but [also] the most honest and fair business man" he knew. Initially, meetings with the board chairman allowed John to verify the feasibility of the productive opportunities. In the development of PO 2.1, the 
chairman introduced the founders to a consultant for pooling more advice and supporting a potential diagnostic component of PO 2.1, as well as to diagnostic companies that could become potential partners.

Pooling was used to create confidence and maintain investors or other potential partners interested in the productive opportunities. Networking with these potential partners was a key aspect to the success of pooling, in particular during the fundraising phase. The board chairman of the parent firm provided introductions to other venture capitalists but was not transparent about his own financing intention, as John explained:

It might mean that he has no interest other than being a consultant or it might mean that he has extreme high level of interest and he doesn't want to show his hand.

During the search for seed financing (approximately a 2-year period between 2014 and 2016), John presented BioCure's business proposition at numerous industry trade shows and venture capitalist events. He continuously pooled information and support from various actors, gaining further network connections, scientific and market verification, and legitimacy. When John secured a round of seed funding in June 2016, his extensive pooling for support brought the potential investors together and included the board chairman as a seed investor. The pooling mechanism among the investors increased the positive assessment of the emergent firm's capabilities.

The pooling mechanism was also used to garner scientific support and is apparent in PO 2.1. Here, pooling was insufficient by itself as a mechanism to address uncertainty. The founders were unable to pool enough support to establish confidence from the business development manager, despite having the positive assessment and support of the academics.

Lastly, John engaged in staging, which was a deliberate phasing of small step progression to address uncertainty. The use of staging was less apparent during PO 2.1 than in the subsequent POs. However, during the negotiations of PO 2.1, the founder did employ some staging or was aware that staging was necessary. The following quotation exemplifies this:

the relationship is built with lots of communication, a little bit of humor, just to keep things moving. We'll be down there once a month or less, keep talking, not be in their face, just stop by and have short meetings.
Yet, the data from PO 2.1 provided indications that perhaps the collaboration was not broken down into small enough parts to "stage" acceptance. The founders claimed that "University 1 were confused about the business structure."

PO 2.3 is a good example of how John used staging. Proposals or pitches became more focused on particular projects with clear boundaries and less focused on creating a complex business undertaking together. He consciously chose to call the model of collaboration with PO 2.3 "open innovation," picking up on the "latest trend." The open innovation model suggested that Hospital 2 and BioCure would collaborate on a number of research projects. This was a first step in establishing legitimacy. The proposal to Hospital 2 differed substantially from the complex collaboration that evolved through the discussions with University 1 . In the initial proposal, John included a detailed project outline on one A4 page, with clear boundaries around the research project. The staging mechanism allowed the founder to reduce uncertainty and start a project. He described how he made this transition:

Until recently I have resisted pursuing low value "starter" projects to engage pharmaceutical partnerships. Instead I have focused on the "all in" discovery partnership model previously ... [but it has] a higher threshold for eventual engagement.

\section{Discussion and conclusion}

Our evidence shows that the process of development of productive opportunities in the emergence stage of a science-based firm is not straightforward. The contingencies and timing of various events, activities, and actions lead to a myriad of possible productive opportunities (around certain technological bases) for the science-based firm. However, our data demonstrate that the realization of productive opportunities is dependent on the conditions and reduction of uncertainty surrounding them. In this section, we discuss the process of productive opportunity development and realization that emerged from our data and the implications of our study for the extant literature.

The process that we illustrate (Fig. 3) is a snapshot of a recursive cycle of changing productive opportunity development. Over a period of time, the process repeats with 


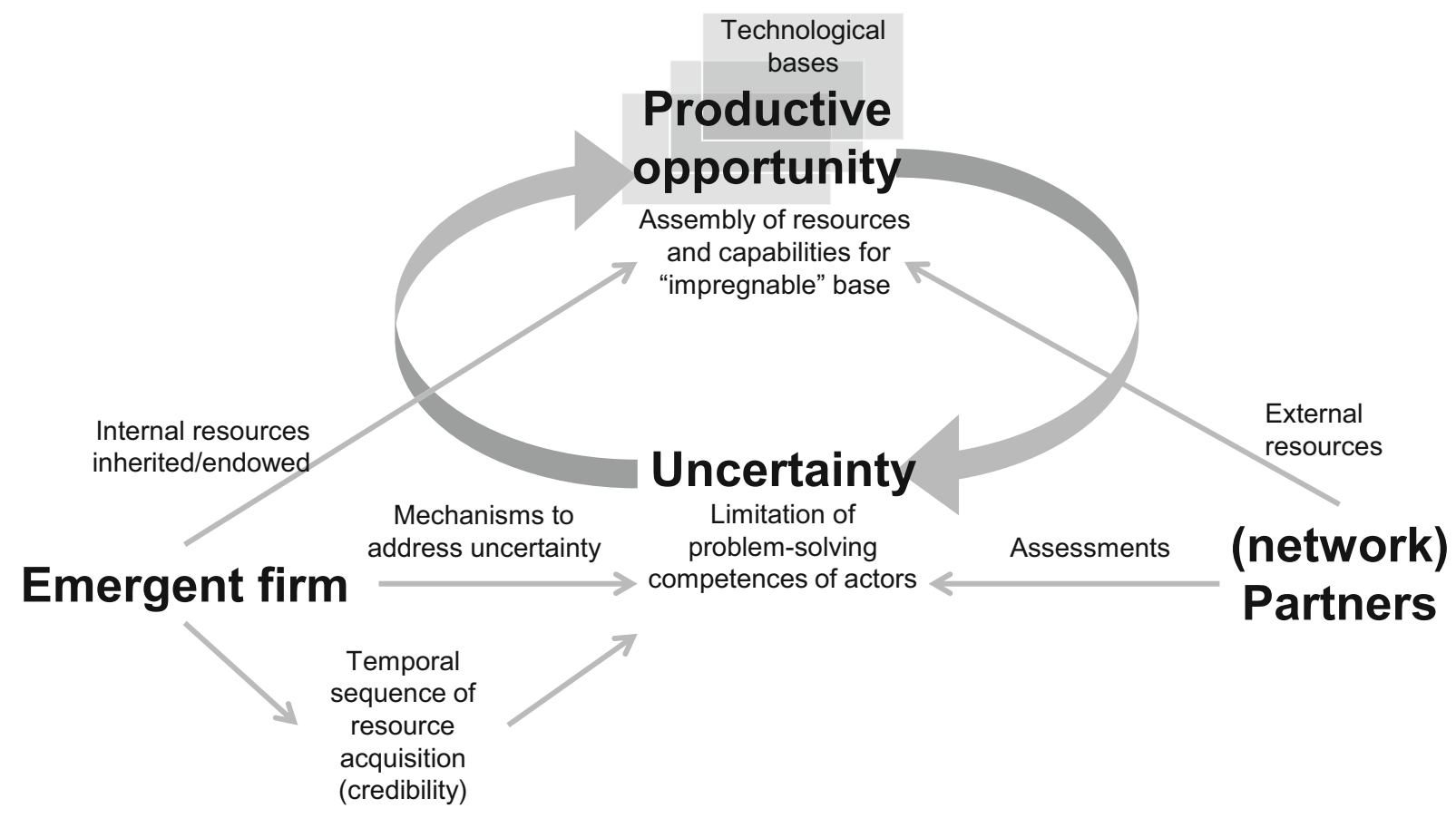

Fig. 3 Process of productive opportunity development

each cycle of resource assembly and productive opportunity development. The process is also confined to the stage of emergence as we argue that emerging science-based firms have more difficulties in securing complementary resources and external partners to realize productive opportunities because tacit knowledge is particularly high at early stage of science-based developments.

Although there is a range of possible productive opportunities open to the science-based firm, depending on its inherited resources (especially technological knowledge), there are also limitations due to the need to access resources from external (network) partners to exploit them. Each productive opportunity has a high level of specificity as the partners define and construct the boundaries and possibilities of the productive opportunity. There is a time-limited nature to these highly specific productive opportunities, which creates a limited window of opportunity for exploitation. If this window of opportunity is missed, because uncertainty surrounding the productive opportunity cannot be sufficiently reduced, then it is unlikely that the productive opportunity will be realized with another partner constellation. Productive opportunities evolve through a process of search, and the changing productive opportunities chart science-based firms' possibilities and directions of emergence and growth. Although it may be possible to go back to an external partner, the time-limited nature of the opportunity generates a change in the characteristics of the productive opportunity (disease orientation, technical rationale, market rationale, and resources required). Our data provide a glimpse of this phenomenon when PO 2.1 was briefly realized with another research department at University 1 to test a refined hypothesis regarding GI diseases.

We show that the iterative cycle in this process lies in the assessment of uncertainty. Uncertainty is both endogenous to innovation and a source of firm emergence. It profoundly affects the value of the productive opportunities for the innovating firm and its external partners. Our data reveal that an entrepreneur's ability to recognize uncertainty and create mechanisms to reduce it sufficiently to help its partners develop better knowledge for framing and assessing the firms' capabilities affects directly the realization of productive opportunities. These mechanisms to address uncertainty influence the problem-solving competence of actors to interpret information about the productive opportunity and to derive a course of action. The entrepreneur must also recognize and interpret the different assessments (e.g., scientific, legal, and reputational) used to gauge uncertainty (by the potential partners) and the different mechanisms (envisioning, pooling, and staging) to address it. This aligns with extant literature that show that symbolic actions of credibility and legitimacy are important in contexts of high uncertainty where assessment by resource providers is difficult (Zott and Huy 2007). 
Lastly, we see that the variation in the temporal sequencing of the emergent science-based firm's resource acquisition (in the establishment of an impregnable base) affects how partners view uncertainty. This temporal sequencing of resource acquisition may act as a signaling device to potential partners and in effect also acts as a mechanism to address uncertainty surrounding productive opportunities (see Miozzo and DiVito 2016). This is congruent with Dosi and Egidi (1991) who argue that innovation is an endogenous mechanism to generate uncertainty and that actor-specific routines reduce environmental complexity and uncertainty. Our study illuminates the variation in the temporal sequencing of resource acquisition. Nevertheless, future studies would need to investigate if this is indeed a signaling mechanism that reduces uncertainty in the context of productive opportunity development and realization.

\subsection{Implications}

The implications of this study suggest important extensions to existing conceptual work. In particular, we build on and extend two areas of research: (1) resource-based studies of science-based firm emergence (Vohora et al. 2004; Wright et al. 2004) and (2) entrepreneurship and the development of productive opportunities (McKelvey 2016; Nason and Wiklund 2015).

First, our study contributes to a growing field exploring science-based firm emergence from a resource-based perspective, which examines the resources and capabilities of such firms, and the nature of firm growth. While this literature has provided rich insights into the specific resources and capabilities at the early stage of growth of science-based firms, two areas have received less attention: the concern with knowledge and development of a technology base, and a dynamic perspective of how these are developed (Druilhe and Garnsey 2004; Mustar et al. 2006; Wright et al. 2004).

Our study delves into the emergence and development of the science-based firm as a function of productive opportunities around the development of technological bases and external partnerships and adopts a dynamic perspective of firm emergence. We show firm emergence as a process of search and development of evolving productive opportunities and the associated construction of a network of partnerships. We show how different technological bases create the possibility of different productive opportunities and influence the entrepreneurial process and resource requirements. We probe into how productive opportunities require the assembly of different internal and external resources, and therefore partners, and address explicitly how the firm and its potential partners gather information to ascertain and address uncertainty. It is our hope that this study encourages other scholars to consider further the relationship between firm emergence and uncertainty.

Second, our findings build on and extend the concept of productive opportunities developed by Penrose (1959/ 2009), contributing to greater theoretical precision of this concept of opportunities and therefore enabling more fruitful design for empirical investigation. By exploring further the relation between productive opportunities and uncertainty and conceptualizing the mechanisms that different organizations involved in decision-making use to address such uncertainty, we define and clarify the concept of productive opportunities. We explore how those opportunities result from the technological base of the firm and are associated with the particular characteristics of the technology. By extending Penrose's concept of productive opportunities, this paper addresses recent calls for resource-oriented firm growth studies to build more directly upon Penrose (Nason and Wiklund 2015).

\section{Conclusion}

We consider our study an initial step in understanding the interaction between firm emergence, productive opportunities, and uncertainty. We call for further research to understand the difficulties in addressing the relation between productive opportunities and uncertainty. It is likely that when firms pursue opportunities requiring interorganizational relationships with complex partners, such as with universities, where academics and administrators have different forms of assessments of whether the perceived capabilities of the emergent firm meet their required standards, uncertainty is more difficult to overcome (as opposed to relations with pharmaceutical firms and venture capitalists). Future research could explore whether factors such as past experience of collaborative engagement with other emerging science-based firms can mitigate uncertainty in those cases.

Our study offers new conceptual insights into firm emergence and especially into the relation between productive opportunities and uncertainty. We acknowledge the challenges to test empirically and extend the analytical framework developed in this study. A major challenge for a large-scale empirical testing is the ability to 
operationalize in a large data set the productive opportunities, uncertainty, and the mechanisms used to address it. Nevertheless, our study offers insights into productive opportunity development and realization that may be applicable to other firms and industries where innovation and technology play an essential role.

Acknowledgments The authors express their sincerest gratitude and appreciation for the cooperation of the founders and other participants in this study that provided generous access to their time, processes, and documentation of their entrepreneurial journey. We are also grateful to our colleagues at the Workshop on Medical Innovation held at Science Policy Research Unit, University of Sussex and to the editors of the Special Section for the insightful and constructive comments we received on earlier versions of the manuscript. This research has been supported by the UK Economic and Social Research Council [RES 189-25-0227].

Open Access This article is distributed under the terms of the Creative Commons Attribution 4.0 International License (http:// creativecommons.org/licenses/by/4.0/), which permits unrestricted use, distribution, and reproduction in any medium, provided you give appropriate credit to the original author(s) and the source, provide a link to the Creative Commons license, and indicate if changes were made.

\section{References}

Acs, Z. J., Braunerhjelm, P., Audretsch, D. B., \& Carlsson, B. (2009). The knowledge spillover theory of entrepreneurship. Small Business Economics, 32(1), 15-30. https://doi. org/10.1007/s11187-008-9157-3.

Adner, R., \& Kapoor, R. (2010). Value creation in innovation ecosystems: how the structure of technological interdependence affects firm performance in new technology generations. Strategic Management Journal, 31, 306-333. https://doi.org/10.1002/smj.821.

Almeida, P., Dokko, G., \& Rosenkopf, L. (2003). Startup size and the mechanisms of external learning: increasing opportunity and decreasing ability? Research Policy, 32, 301-315. https://doi.org/10.1016/S0048-7333(02)00101-4.

Alvarez, S. A., \& Barney, J. B. (2007). Discovery and creation: alternative theories of entrepreneurial creation. Strategic Entrepreneurship Journal, 1(1), 11-26. https://doi. org/10.1002/sej.4.

Alvarez, S. A., Barney, J. B., \& Anderson, P. (2013). Forming and exploiting opportunities: the implications of discovery and creation processes for entrepreneurial and organizational research. Organization Science, 24, 301-317. https://doi. org/10.1287/orsc.1110.0727.

Balogun, J., \& Johnson, G. (2004). Organizational restructuring and middle manager sensemaking. Academy of Management Journal, 47(4), 523-549. https://doi.org/10.2307/20159600.

Beckman, C. M., Haunschild, P. R., \& Phillips, D. J. (2004). Friends or strangers? Firm-specific uncertainty, market uncertainty and network partner selection. Organization Science, 15, 259-275. https://oi.org/10.1287/orsc.1040.0065.
Breschi, S., Malerba, F., \& Orsenigo, L. (2000). Technological regimes and Schumpeterian patterns of innovation. Economic Journal, 110, 388-410. https://doi.org/10.1111/1468-0297.00530.

Brown, A. D. (2006). A narrative approach to collective identities. Journal of Management Studies, 43(4), 731-753. https://doi. org/10.1111/j.1467-6486.2006.00609.x.

Corley, K. G., \& Gioia, D. A. (2004). Identity ambiguity and change in the wake of a corporate spin-off. Administrative Science Quarterly, 49(2), 173-208. https://doi.org/10.2307 14131471 .

Danneels, E. (2002). The dynamics of product innovation and firm competences. Strategic Management Journal, 23, 10951121. https://doi.org/10.1002/smj.275.

Davidsson, P. (2015). Entrepreneurial opportunities and the entrepreneurship nexus: a re-conceptualization. Journal of Business Venturing, 30(5), 674-695. https://doi.org/10.1016 /j.jbusvent.2015.01.002.

Dosi, G. (1988). Technological paradigms and technological trajectories: a suggested interpretation of the determinants and directions of technical change. Research Policy, 11(3), 147162. https://doi.org/10.1007/BF01198306.

Dosi, G., \& Egidi, M. (1991). Substantive and procedural uncertainty: an exploration of economic behaviours in changing environments. Journal of Evolutionary Economics, 1(2), 145-168. https://doi.org/10.1007/BF01224917.

Dosi, G., Freeman, C., Nelson, R., Silverberg, G., \& Soete, L. (Eds.). (1988). Technical change and economic theory. London: Pinter.

Dow, S. C. (2014). Addressing uncertainty in economics and the economy. Cambridge Journal of Economics, 39, 33-47. https://doi.org/10.1093/cje/beu022.

Druilhe, C., \& Garnsey, E. (2004). Do academic spin-off firms differ and does it matter? Journal of Technology Transfer, 29, 269-285. https://doi.org/10.1023/B:JOTT.00000.

Dubois, A., \& Gadde, L. E. (2002). Systematic combining: an abductive approach to case research. Journal of Business Research, 55(7), 553-560. https://doi.org/10.1016/S01482963(00)00195-8.

Eckhardt, J., \& Shane, S. A. (2003). Opportunities and entrepreneurship. Journal of Management, 29(3), 333-349. https://oi.org/10.1177/014920630302900304.

Ellsberg, D. (1961). Risk, Ambiguity, and the Savage Axioms. The Quarterly Journal of Economics, 75(4), 643-669.

Freeman, C. (1982). The economics of industrial innovation. London: Pinter.

Garnsey, E., \& Leong, Y. Y. (2008). Combining resource-based and evolutionary theory to explain the genesis of bio-networks. Industry and Innovation, 15(6), 669-686. https://doi. org/10.1080/13662710802565271.

Gioia, D. A., Corley, K. G., \& Hamilton, A. L. (2013). Seeking qualitative rigor in inductive research: notes on the Gioia methodology. Organizational Research Methods, 16(1), 15-31. https://doi.org/10.1177/1094428112452151.

Graffin, S. D., \& Ward, A. J. (2010). Certifications and reputation: determining the standard of desirability amidst uncertainty. Organization Science, 21(2), 331-334. https://doi. org/10.1287/orsc. 1080.0400 .

Hagedoorn, J., \& Duysters, G. (2002). External sources of innovative capabilities: the preferences for strategic alliances or mergers and acquisitions. Journal of Management Studies, 39(2), 167-188. https://doi.org/10.1111/1467-6486.00287. 
Hay, F. G. (1980). Imagination and the nature of choice by George L.S. Schackle Review. The Economic Journal, 90(358), 397-399.

Heirman, A., \& Clarysse, B. (2004). How and why do researchbased start-ups differ at founding? A resource-based configurational perspective. Journal of Technology Transfer, 29, 247-268. https://doi.org/10.1023/B:JOTT.00000.

Hite, J. M., \& Hesterley, W. S. (2001). The evolution of firm networks: from emergence to early growth of the firm. Strategic Management Journal, 33, 275-386. https://doi. org/10.1002/smj.156.

Katila, R., \& Mang, P. Y. (2003). Exploiting technological opportunities: the timing of collaborations. Research Policy, 32, 317-332. https://doi.org/10.1016/S0048-7333(02)00102-6.

Keynes, J. M. (1921). A treatise on probability, reprinted in Keynes, J. M. (Eds) (1973) Collected Writings, vol.VIII, London: Macmillan, for the Royal Economic Society.

Klevorick, A. K., Levin, R. C., Nelson, R. R., \& Winter, S. G. (1995). On the sources and significance of interindustry differences in technological opportunities. Research Policy, 24, 185-205. https://doi.org/10.1016/0048-7333(93)00762-I.

Knight, F. (1921). Risk, uncertainty and profit. Boston: Houghton Mifflin.

Langley, A. (1999). Strategies for theorizing from process data. Academy of Management Review, 24(4), 691-710. https://doi.org/10.5465/AMR.1999.2553248.

Langley, A., Smallman, C., Tsoukas, H., \& van de Ven, A. (2013). Process studies of change in organization and management: unveiling temporality, activity, and flow. Academy of Management Journal, 56(1), 1-13. https://doi.org/10.5465 lamj.2013.4001.

Laursen, K. (2012). Keep searching and you'll find: what do we know about variety creation through firms' search activities for innovation? Industrial and Corporate Change, 21(5), 1181-1220. https://doi.org/10.1093/icc/dts025.

Lawson, T. (1988). Probability and uncertainty in economic analysis. Journal of Post Keynesian Economics, 11(1), 38-65. https://doi.org/10.1080/01603477.1988.11489724.

Levin, R. C., Klevorick, A. K., Nelson, R. R., \& Winter, S. G. (1987). Appropriating the returns from industrial research and development. Brookings Papers on Economic Activity, 3, 783-831.

Lewin, K. (1946). Action research and minority problems. Journal of Social Issues, 2(4), 34 46. https://doi.org/10.1111/j.15404560.1946.tb02295.x.

Loasby, B. J. (2002). The evolution of knowledge: beyond the biological model. Research Policy, 31, 1227-1239. https://doi.org/10.1016/S0048-7333(02)00060-4.

Lockett, A., Wiklund, J., Davidsson, P., \& Girma, S. (2011). Organic and acquisitive growth: re-examining, testing, and extending Penrose's growth theory. Journal of Management Studies, 48(1), 48-74. https://doi.org/10.1111/j.1467-6486.2009.00879.x.

Malerba, F., \& Orsenigo, L. (1996). Schumpeterian patterns of innovation are technology-specific. Research Policy, 25(3), 451-478. https://doi.org/10.1016/0048-7333(95)00840-3.

Malerba, F., \& Orsenigo, L. (1997). Technological regimes and sectoral patterns of innovative activities. Industrial and Corporate Change, 6(1), 83-117. https://doi.org/10.1093 icc/6.1.83.

Markman, G. D., Siegel, D. S., \& Wright, M. (2008). Research and technology commercialization. Journal of Management Studies, 45, 1401-1423. https://doi.org/10.1111/j.14676486.2008.00803.x.
McKelvey, M. (2016). Firms navigating through innovation spaces: a conceptualization of how firms search and perceive technological, market and productive opportunities. Journal of Evolutionary Economics, 26, 785-802. https://doi. org/10.1007/s00191-016-0478-0.

Melrose, M. J. (2001). Maximizing the rigor of action research: why would you want to? How could you? Field Methods, 13(2), 160-180. https://doi.org/10.1177/1525822X0101300203.

Miozzo, M., \& DiVito, L. (2016). Growing fast or slow?: understanding the variety of paths and the speed of early growth of entrepreneurial science-based firms. Research Policy, 45(5), 964-986. https://doi.org/10.1016/j.respol.2016.01.011.

Mustar, P., Renault, M., Colombo, M., Piva, E., Fontes, M., Lockett, A., Wright, M., Clarysse, B., \& Moraye, N. (2006). Conceptualising the heterogeneity of research-based spin-offs: a multi-dimensional taxonomy. Research Policy, 35, 289-308. https://doi.org/10.1016/j.respol.2005.11.001.

Mytelka, L. (1990). Strategic partnerships: states, firms and international competition. London: Pinter.

Nason, R., \& Wiklund, J. (2015). An assessment of resource-based theorizing on firm growth and suggestions for the future. Journal of Management. https://doi.org/10.1177 /0149206315610635.

Nelson, R. R., \& Winter, S. G. (1982). An evolutionary theory of economic change. Cambridge: Harvard University Press.

Penrose, E. (1959/2009). The theory of the growth of the firm. Oxford: Oxford University Press.

Pentland, B. T. (1999). Narrative methods in collaborative systems research. In systems sciences, HICSS-32. Proceedings of the 32nd Annual Hawaii International Conference. IEEE. https://doi.org/10.1109/HICSS.1999.772719.

Pisano, G. (2006). Science business: the promise, the reality and the future of biotech. Cambridge: Harvard Business Press.

Powell, W. W., Koput, K., \& Smith-Doerr, L. (1996). Interorganizational collaboration and the locus of innovation: networks of learning in biotechnology. Administrative Science Quarterly, 41, 116-145. https://doi.org/10.2307/2393988.

Rasmussen, E., Mosey, S., \& Wright, M. (2011). The evolution of entrepreneurial competences: a longitudinal study of university spin-off venture emergence. Journal of Management Studies, 48(6), 1314-1335. https://doi.org/10.1111/j.14676486.2010.00995.x.

Rosenberg, N. (1982). Inside the black box. Cambridge: Cambridge University Press.

Rothaermel, F. T., Agung, S. D., \& Jiang, L. (2007). University entrepreneurship: a taxonomy of the literature. Industrial and Corporate Change, 16, 691-791. https://doi.org/10.1093 /icc/dtm023.

Sarason, Y., Dean, T., \& Dillard, J. F. (2006). Entrepreneurship as the nexus of individual and opportunity: a structuration view. Journal of Business Venturing, 21(3), 286-305. https://doi. org/10.1016/j.jbusvent.2005.02.007.

Shackle, G. L. S. (1979). Imagination and the nature of choice. Edinburgh: Edinburgh University Press.

Shane, S. (2000). Prior knowledge and the discovery of entrepreneurial opportunities. Organization Science, 11, 448-469. https://doi.org/10.1287/orsc.11.4.448.14602.

Shane, S., \& Venkataraman, S. (2000). The promise of entrepreneurship as a field of research. Academy of Management Review, 25(1), 217-226. https://doi.org/10.5465 /AMR.2000.2791611. 
Siegel, D. S., Veugelers, R., \& Wright, M. (2007). Technology transfer offices and commercialization of university intellectual property: performance and policy implications. Oxford Review of Economic Policy, 23(4), 640-660. https://doi. org/10.1093/oxrep/grm036.

Strauss, A., \& Corbin, J. M. (1997). Grounded theory in practice. London: Sage.

Teece, D. J. (1986). Profiting from technological innovation: implications for integration, collaboration, licensing and public policy. Research Policy, 15(6), 285-305. https://doi. org/10.1016/0048-7333(86)90027-2.

Tripsas, M. (1997). Unraveling the process of creative destruction: complementary assets and incumbent survival in the typesetter industry. Strategic Management Journal, 18(1), 119-142. https://doi.org/10.1002/(SICI)1097-0266(199707)18 $: 1+<119::$ AID-SMJ921>3.0.CO;2-0.

Tsoukas, H., \& Chia, R. (2002). On organizational becoming: rethinking organizational change. Organization Science, 13(5), 567-582. https://doi.org/10.1287/orsc.13.5.567.7810.

Van de Ven, A. H., \& Poole, M. S. (2005). Alternative approaches for studying organizational change. Organization Studies, 26(9), 1377-1404. https://doi.org/10.1177/0170840605056907.
Vohora, A., Wright, M., \& Lockett, A. (2004). Critical junctures in the growth in university high-tech spinout companies. Research Policy, 33, 147-175. https://doi.org/10.1016 /S0048-7333(03)00107-0.

von Hippel, E. (1988). The sources of innovation. New York: Oxford University Press.

Wood, M. S., \& McKinley, W. (2010). The production of entrepreneurial opportunity: a constructivist perspective. Strategic Entrepreneurship Journal, 4(1), 66-84. https://doi. org/10.1002/sej.83.

Wright, M., Vohora, A., \& Lockett, A. (2004). The formation of high tech university spinout companies: the role of joint ventures and venture capital investors. Journal of Technology Transfer, 29, 287-310. https://doi.org/10.1023 /B:JOTT.0000034124.70363.83.

Yin, R. K. (1994). Case study research. Newbury Park: Sage.

Zott, C., \& Huy, Q. N. (2007). How entrepreneurs use symbolic management to acquire resources. Administrative Science Quarterly, 52(1), 70-105. https://doi.org/10.2189/asqu.52.1.70. 